\title{
MESH SIZE AND BIRD CAPTURE RATES IN MATO GROSSO DO SUL STATE, BRAZIL
}

\author{
PIRATELLI, A. \\ Departamento de Biologia Animal, Instituto de Biologia, Universidade Federal Rural do \\ Rio de Janeiro, Seropédica, RJ, Brazil \\ Correspondence to: Augusto Piratelli, Departamento de Biologia Animal, Instituto de Biologia, Universidade \\ Federal Rural do Rio de Janeiro, BR 465, km 07, CEP 23890-000, Seropédica, RJ, Brazil, e-mail: pirateli@ufrrj.br \\ Received March 18, 2002 - Accepted May 15, 2002 - Distributed February 28, 2003
}

(With 2 figures)

\begin{abstract}
Mist-nets alternating 36- $\mathrm{mm}$ and 61-mm mesh in woods and low vegetation of "cerrado" (Brazilian savanna) tested bird-capture efficiency relative to bird length and mass. Of 1,296 birds captured and 102 species, 785 (93 species) were with 36-m mesh and 511 (69 species) with 61-mm mesh. The 61-mm mesh improved capture rates only for some larger species; so, in general, 36-mm mesh mistnets are more appropriate for field work in "cerrado" areas.
\end{abstract}

Key words: Central Brazil, Cerrado, mesh size, mist nets.

\section{RESUMO}

\section{Tamanho de malhas e taxas de capturas de aves no Estado de Mato Grosso do Sul, Brasil}

Este trabalho teve por objetivo comparar a eficiência na captura de aves, relativamente à massa corporal e ao comprimento total, de redes ornitológicas de malhas de 36 e $61 \mathrm{~mm}$. O estudo foi realizado em área de Cerrado, dispondo-se as redes alternadamente em transectos lineares. Das 1.296 capturas e 102 espécies, 785 ( 93 espécies) foram efetuadas com redes de $36 \mathrm{~mm}$ e 511 (69 espécies) com redes de malha de $61 \mathrm{~mm}$. De modo geral, as últimas redes não aumentaram as taxas de capturas, exceto para as espécies maiores e com maior massa corporal, e as redes de malha de $36 \mathrm{~mm}$ seriam mais apropriadas para estudos em área de Cerrado.

Palavras-chave: Brasil Central, Cerrado, tamanhos de malha, redes ornitológicas.

\section{INTRODUCTION}

Mist nets have often been used for bird studies, and their results compared with other methods (e.g., Ralph et al., 1993; Rappole et al., 1998; Poulin et al., 2000). Rappole et al. (1998) have proposed a methodology that combines two procedures (mist nets and point counts) to provide a more accurate assessment of avian habitat use. According to Poulin et al. (2000), while point counts are less demanding in the field, the manipulation of netted birds allows documentation of various aspects of their biology. However, a lot of restrictions concerning mist-net use were listed by Remsen \& Good (1996).
When mist nets are employed, the question arises as to which mesh size produces more captures per hour, since one reason why an individual cannot be sampled is its size; it can be too big or too small to get tangled in nets (MacArthur \& MacArthur, 1974). Jenni et al. (1996) determined capture efficiency of 36-mm-mesh by observing birds flying towards the nets in various habitats. They concluded that different species (morphology and body mass) and climatic conditions (wind, shade) can provide different capture rates for 36-mm nets.

Some authors have also examined mesh size as a factor affecting bird capture rates (e.g., Heimerdinger \& Leberman, 1966; Pardieck \& Waide, 1992). 
With this objective, Karr (1981) indicated that $36-\mathrm{mm}$-mesh nets were the most effective ones for a wide range of birds encountered in most terrestrial habitats, and these have been most frequently used (Karr, 1980; Blake \& Loiselle, 1991; Loiselle \& Blake, 1994). Pardieck \& Waide (1992) observed however, that in most works involving mist-net captures, mesh size is not mentioned. From 25 studies on birds, using mist nets that the authors reviewed, in only four of them mesh size was specified. In more recent works, one can find a similar situation; as it has been exemplified by Young et al. (1998) for Costa Rican birds; Silkey et al. (1999) for Californian birds; Reinert et al. (1996), Marini et al. (1997), Oniki \& Willis (1999) and Stratford \& Stouffer (1999) (the four latter about Brazilian birds).

The goal of the present study was to compare bird capture efficiency of two mesh sizes (36 and $61 \mathrm{~mm}$ ) in areas of cerrado and some other habitats of Mato Grosso do Sul State, Central Brazil.

\section{MATERIALS AND METHODS}

From ten to sixteen 36- and 61-mm-mesh mistnets were alternately spaced for 28 months (August 1994 to December 1996) in linear transects.

All nets had the same dimension $(12 \times 2 \mathrm{~m})$ and were operated for the same length of time (usually from 5:30 am to 3:00 pm) in 14 locations. These study plots were located on large eucalyptus plantations outside the cities of Brasilândia $\left(21^{\circ} 25^{\prime} \mathrm{S} ; 52^{\circ} 03^{\prime} \mathrm{W}\right)$, with three study sites; Selvíria (20³6'S; $\left.51^{\circ} 41^{\prime} \mathrm{W}\right)$, with two study sites; and Três Lagoas ( $\left.20^{\circ} 75^{\prime} \mathrm{S} ; 51^{\circ} 67^{\prime} \mathrm{W}\right)$, with nine study sites. Eucalyptus plantations belong to the paper manufacture and cellulose products industry, and large plantations of this exotic species coexist with fragments of native vegetation.

The fourteen study sites sampled five different vegetation types, with varying degrees of human disturbance: "cerrado" strictu sensu (five study sites - 3,750 net-hours); "cerradão" - a closed-canopy tall cerrado (five study sites $-5,300$ net-hours); gallery forest (one study site $-2,370$ net-hours); degraded second-growth forest (one study site - 710 net hours), and eucalyptus plantations with and without understory (two study sites $-1,400$ net-hours). Although sampling effort varied between study sites, both 36- $\mathrm{mm}$ and 61- mm mesh nets were always simultaneously used in equal numbers. Chi square tests were used to check statistical significance of different capture rates, and Yates' Correlation was used when there were only two categories in a distribution (Fowler \& Cohen, 1995). All captured birds were banded with bands supplied by Cemave/Ibama.

For alternating 36- and 61-mm mesh nets, I compared captures relative to bird length (measured by means of a metal ruler) and body mass (measured with 50-, 100-, 300-, and $1000 \mathrm{~g}$ spring scales). The term "efficiency" is used here to indicate the mesh size that has captured the number of individuals of each species per unit of effort.

\section{RESULTS AND DISCUSSION}

In 13,468 net-hours, I captured 1,296 birds: $785(60.6 \%)$, with 36-mm, and 511 (39.4\%), with 61-mm mesh $\left(\chi^{2}=28.96\right.$; d.f. $\left.=1 ; \mathrm{p}=0.01\right)$. Of 102 captured species, 93 were caught by $36-\mathrm{mm}$ mesh (91.2\% of the total), while nets of larger mesh captured 69 species $(67.6 \%)\left(\chi^{2}=3.56\right.$; d.f. $=1$; $\mathrm{p}=0.1$ ).

The smaller mesh nets captured most individuals and species (Table 1). Platyrhynchus mystaceus, one of the smallest species, was only captured with 36-mm mesh nets. However, for some larger species, the 61-mm mesh was more efficient. This is the case of Piaya cayana (only captured with these nets), Momotus momota, some doves (Leptotila verreauxi, L. rufaxilla and Claravis pretiosa), and Passeriformes (Taraba major and Automolus leucophthalmus).

For 12 species, differences in capture rates were statistically significant. Ten species were more captured with 36-mm mesh: Cnemotriccus fuscatus $\left(\chi^{2}=13.60 ; \mathrm{p}=0.01\right)$ Basileuterus flaveolus $\left(\chi^{2}=\right.$ 5.94; $\mathrm{p}=0.05)$, Amazilia fimbriata $\left(\chi^{2}=4.00 ; \mathrm{p}=\right.$ $0.05)$, Camptostoma obsoletum $\left(\chi^{2}=5.82 ; \mathrm{p}=0.05\right)$, Hemitriccus margaritaceiventer $\left(\chi^{2}=5.06 ; \mathrm{p}=\right.$ $0.05)$, Vireo chivi $\left(\chi^{2}=4.92 ; \mathrm{p}=0.05\right)$, Platyrhynchus mystaceus $\left(\chi^{2}=10.8 ; \mathrm{p}=0.01\right)$, Poecilurus scutatus $\left(\chi^{2}=7.69 ; \mathrm{p}=0.01\right)$, Pipra fasciicauda $\left(\chi^{2}=10.41 ; \mathrm{p}=0.01\right)$, and Dysithamnus mentalis $\left(\chi^{2}=9.33 ; \mathrm{p}=0.01\right)$. Only two species were captured more with 61-mm mesh: Piaya cayana $\left(\chi^{2}=9.14 ; \mathrm{p}=0.01\right)$ and Leptotila verreauxi $\left(\chi^{2}=8.47 ; \mathrm{p}=0.01\right)$. This suggests that the 36-mm mesh nets were more efficient for several captured species. 
TABLE 1

Number of captures (except recaptures) and species with 36- and 61-mm mesh, with mean body mass (g) and mean total length (mm). See Piratelli et al. (2001) for more morphological data.

\begin{tabular}{|c|c|c|c|c|}
\hline Species & Mean body mass (g) & Mean total length (mm) & $36 \mathrm{~mm}$ & $61 \mathrm{~mm}$ \\
\hline Crypturellus tataupa & - & 207.5 & 0 & 2 \\
\hline Rupornis magnirostris & - & - & 1 & 0 \\
\hline Columbina minuta & - & - & 1 & 0 \\
\hline Columbina talpacoti & 49.7 & 167.4 & 5 & 9 \\
\hline Claravis pretiosa & 54.3 & 183.9 & 6 & 11 \\
\hline Leptotila rufaxilla & 144.8 & 249.1 & 7 & 12 \\
\hline Leptotila verreauxi & 157.7 & 259.5 & 3 & 14 \\
\hline Geotrygon montana & - & 180.0 & 1 & 0 \\
\hline Piaya cayana & 111.9 & 474.2 & 0 & 7 \\
\hline Coccyzus melacoryphus & 44.0 & 255.5 & 1 & 1 \\
\hline Glaucidium brasilianum & 64.0 & 162.0 & 0 & 1 \\
\hline Nyctidromus albicollis & - & 275.0 & 2 & 0 \\
\hline Hydropsalis torquata & - & 290.0 & 0 & 1 \\
\hline Phaethornis pretrei & - & - & 1 & 0 \\
\hline Colibri serrirostris & 6.5 & 108.0 & 1 & 0 \\
\hline Chrysolampis mosquitus & - & - & 1 & 0 \\
\hline Thalurania furcata & 4.8 & 99.3 & 3 & 0 \\
\hline Chlorostilbon aureoventris & 4.5 & 85.5 & 1 & 1 \\
\hline Hylocharis chrysura & 3.2 & 85.7 & 4 & 0 \\
\hline Amazilia fimbriata & 4.3 & 90.2 & 8 & 1 \\
\hline Anthrachotorax nigricollis & - & - & 1 & 0 \\
\hline Chloroceryle americana & 36.8 & 198.0 & 2 & 0 \\
\hline Momotus momota & 112.6 & 387.9 & 31 & 43 \\
\hline Brachygalba lugubris & 17.5 & 165.0 & 2 & 0 \\
\hline Galbula ruficauda & 25.1 & 215.5 & 3 & 1 \\
\hline Nystalus maculatus & 42.5 & 179.7 & 2 & 6 \\
\hline Nonnula rubecula & 16.6 & 145.9 & 6 & 6 \\
\hline Monasa nigrifrons & 92.0 & 277.4 & 2 & 3 \\
\hline Picumnus cirratus & 10.0 & 120.0 & 1 & 0 \\
\hline Picumnus guttifer & 12.8 & 96.5 & 1 & 1 \\
\hline Picumnus sp. & - & - & 3 & 0 \\
\hline Colaptes melanochloros & - & 226.5 & 1 & 1 \\
\hline Veniliornis passerinus & 30.5 & 142.8 & 3 & 1 \\
\hline Campephilus melanoleucos & - & - & 1 & 0 \\
\hline Taraba major & 53.6 & 209.1 & 4 & 8 \\
\hline Thamnophilus doliatus & 29.1 & 162.3 & 6 & 8 \\
\hline Thamnophilus punctatus & 19.3 & 137.6 & 49 & 31 \\
\hline Dysithamnus mentalis & 14.0 & 108.1 & 18 & 3 \\
\hline Formicivora rufa & 10.8 & 141.0 & 2 & 0 \\
\hline
\end{tabular}


TABLE 1 (Continued)

\begin{tabular}{|c|c|c|c|c|}
\hline Species & Mean body mass (g) & Mean total length (mm) & $36 \mathrm{~mm}$ & $61 \mathrm{~mm}$ \\
\hline Synallaxis frontalis & 15.5 & 145.0 & 4 & 1 \\
\hline Synallaxis albescens & 12.5 & - & 1 & 0 \\
\hline Poecilurus scutatus & 13.7 & 136.4 & 12 & 1 \\
\hline Cranioleuca vulpina & 20.5 & 140.0 & 0 & 1 \\
\hline Automolus leucophthalmus & 30.7 & 175.5 & 4 & 6 \\
\hline Sittasomus griseicapillus & 18.8 & 146.4 & 13 & 11 \\
\hline Dendrocolaptes picumnus & 62.0 & 265.0 & 0 & 1 \\
\hline Dendrocolaptes platyrostris & 58.4 & 253.1 & 9 & 6 \\
\hline Campylorhamphus trochilirostris & - & 241.0 & 2 & 6 \\
\hline Xiphorhynchus guttatus & 34.0 & 258.0 & 1 & 0 \\
\hline Lepidocolaptes angustirostris & 28.7 & 192.5 & 6 & 6 \\
\hline Myiopagis viridicata & 9.9 & 121.5 & 4 & 0 \\
\hline Camptostoma obsoletum & 9.6 & 112.1 & 10 & 1 \\
\hline Elaenia flavogaster & - & - & 2 & 3 \\
\hline Elaenia parvirostris & 15.7 & 132.3 & 2 & 2 \\
\hline Elaenia mesoleuca & 15.6 & 136.3 & 6 & 2 \\
\hline Serpophaga subcristata & - & - & 2 & 0 \\
\hline Phyllomyias fasciatus & - & - & 1 & 0 \\
\hline Leptopogon amaurocephalus & 11.4 & 125.4 & 8 & 4 \\
\hline Corythopis delalandi & - & - & 5 & 3 \\
\hline Hemitriccus margaritaceiventer & 9.0 & 103.1 & 12 & 3 \\
\hline Tolmomyias sulphurescens & 11.0 & 128.0 & 1 & 0 \\
\hline Platyrhynchus mystaceus & 9.6 & 89.9 & 12 & 0 \\
\hline Myiophobus fasciatus & - & - & 1 & 0 \\
\hline Cnemotriccus fuscatus & 13.8 & 33.9 & 58 & 24 \\
\hline Casiornis rufa & 20.6 & 164.4 & 21 & 16 \\
\hline Myiarchus ferox & 24.0 & 178.0 & 0 & 1 \\
\hline Myiarchus tyrannulus & 26.5 & 183.7 & 18 & 16 \\
\hline Pitangus sulphuratus & - & 225.8 & 3 & 2 \\
\hline Myiodynastes maculatus & 47.2 & 213.1 & 4 & 5 \\
\hline Empidonomus varius & 26.6 & 171.6 & 2 & 3 \\
\hline Tyrannus melancholicus & - & - & 1 & 1 \\
\hline Pachyramphus polychopterus & 19.0 & 144.0 & 2 & 1 \\
\hline Tityra cayana & 75.0 & 213.0 & 0 & 1 \\
\hline Lathrotriccus euleri & 16.6 & 138.3 & 4 & 2 \\
\hline Pipra fasciicauda & 15.7 & 104.2 & 47 & 20 \\
\hline Antilophia galeata & 21.8 & 154.3 & 2 & 1 \\
\hline Neopelma pallescens & 20.5 & 144.0 & 2 & 0 \\
\hline Cyanocorax chrysops & 140.3 & 336.3 & 5 & 6 \\
\hline
\end{tabular}


TABLE 1 (Continued)

\begin{tabular}{|c|c|c|c|c|}
\hline Species & Mean body mass (g) & Mean total length $(\mathrm{mm})$ & $36 \mathrm{~mm}$ & $61 \mathrm{~mm}$ \\
\hline Polioptila dumicola & 6.5 & 120.0 & 1 & 0 \\
\hline Turdus nigriceps & 49.0 & 194.0 & 1 & 0 \\
\hline Turdus leucomelas & 66.7 & 222.0 & 44 & 35 \\
\hline Turdus amaurochalinus & 57.1 & 216.1 & 23 & 27 \\
\hline Cyclarhis gujanensis & 28.8 & 150.5 & 13 & 6 \\
\hline Vireo chivi & 15.3 & 124.2 & 11 & 2 \\
\hline Basileuterus flaveolus & 13.9 & 137.0 & 103 & 43 \\
\hline Basileuterus hypoleucus & 10.3 & 117.2 & 5 & 0 \\
\hline Thlypopsis sordida & 14.0 & 130.0 & 2 & 1 \\
\hline Eucometis penicillata & 26.8 & 174.7 & 11 & 5 \\
\hline Tachyphonus rufus & 31.2 & 178.3 & 19 & 10 \\
\hline Trichothraupis melanops & 19.5 & 149.0 & 0 & 1 \\
\hline Habia rubica & 12.0 & 150.0 & 1 & 0 \\
\hline Piranga flava & 24.0 & 185.0 & 1 & 0 \\
\hline Ramphocelus carbo & - & 173.0 & 1 & 0 \\
\hline Thraupis sayaca & 30.1 & 151.0 & 4 & 1 \\
\hline Thraupis palmarum & 40.5 & 170.0 & 2 & 1 \\
\hline Tangara cayana & 22.0 & 129.3 & 3 & 1 \\
\hline Zonotrichia capensis & 14.8 & 138.5 & 2 & 0 \\
\hline Oryzoborus angolensis & 12.0 & 122.0 & 2 & 0 \\
\hline Arremon flavirostris & 23.5 & 149.2 & 4 & 5 \\
\hline Coryphospingus cucullatus & 15.6 & 132.8 & 10 & 3 \\
\hline Saltator similis & 43.1 & 202.7 & 42 & 38 \\
\hline Total of captures & & & 785 & 511 \\
\hline Total of species & & & 93 & 69 \\
\hline
\end{tabular}

The 36-mm mesh nets captured birds from 10 to $450 \mathrm{~mm}$ long $($ mean $=164 \mathrm{~mm}$, s.d. $=64.7)$, while the $61-\mathrm{mm}$ mesh captured birds from 83 to $490 \mathrm{~mm}$ long $($ mean $=199 \mathrm{~mm}$, s.d. $=80.3)$. Both meshes were more efficient for birds between 100 and $149 \mathrm{~mm}$ long, and the 61-mm mesh captured more individuals over $250 \mathrm{~mm}$ long (Fig. 1).

Birds with body masses from $2.5 \mathrm{~g}$ to 265 $\mathrm{g}$ were captured with $36-\mathrm{mm}$ mesh $($ mean $=24.5$ g, s.d. = 25.5). With 61-mm mesh, body masses ranged between $4.5 \mathrm{~g}$ and $186 \mathrm{~g}$ (mean $=36 \mathrm{~g}$, s.d. = 33.8). Both mesh sizes were effective for birds in the 10-20 $\mathrm{g}$ range, even though the $36-\mathrm{mm}$ mesh captured more birds. For birds over $30 \mathrm{~g}$, both meshes captured similar numbers and, in these cases, sometimes the 61-mm mesh was more efficient (Fig. 2).

Although I have found that bird length is related to mesh capture rates, Jenni et al. (1996) indicate that body mass and cranium size are more useful measures than the total length for determining the capture rates, since individuals' capture probability is directly related to head entanglement. Most birds were 10-20 g in three previous studies in southern Brazil (Reinert et al., 1996; Marini et al., 1997; Oniki \& Willis, 1999). 


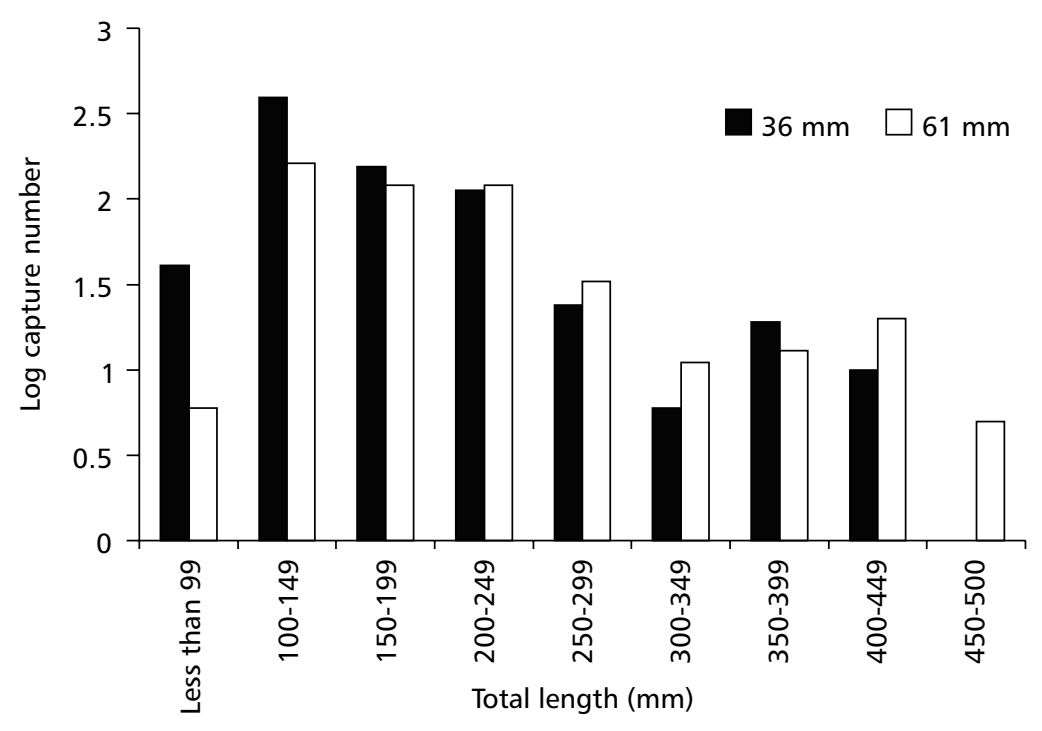

Fig. 1 - Bird total length $(\mathrm{mm})$ and number captured (data transformed in $\log _{10}$ ) with 36 and 61 -mm-mesh mist nets.

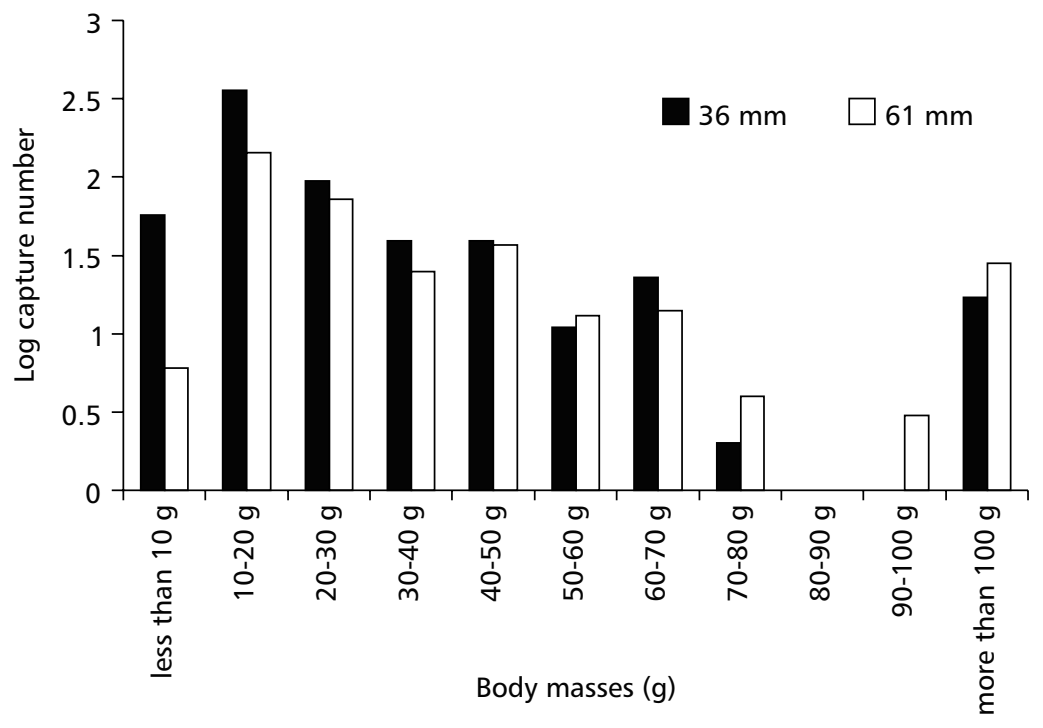

Fig. 2 - Bird body masses (g) and number captured (data transformed in $\log _{10}$ ) with 36 and 61 -mm-mesh mist nets. 
The simultaneous use of two nets has the advantage of improving the abundance estimates for some larger species. In relation to species diversity, the isolated use of smaller mesh nets would produce almost the same results as the simultaneous use of two mesh sizes, at least in these "cerrados" and nearby areas.

By using only 36-mm mesh one can increase the capture rate, particularly when there is a greater density of small birds, which is almost always the case in tropical-forest understories. For bigger, heavier species, the 61-mm mesh would substantially improve capture rates.

Acknowledgments - I appreciate the help of I. Toledo for reviewing the English usage. I thank the students Fernanda Melo, Marcia Pereira, Marcia Siqueira, Mariana Mello and Roslaine Caliri, for their help in data collecting; CEMAVE/ IBAMA for bands and permissions; PICD - CAPES/UFMS for a doctorate fellowship; PROPP/UFMS for financial support; Chamflora Três Lagoas Agroflorestal Ltda. for logistical support and Faperj (Process E-26/170.656/2000) for financial support, allowing the presentation of this data as a poster during the VII Brazilian Ornithological Congress.

\section{REFERENCES}

BLAKE, J. G. \& LOISELLE, B. A., 1991, Variation in resource abundance affects capture rates of birds in three lowland habitats in Costa Rica. Auk, 108: 114-130.

FOWLER, J. \& COHEN, L., 1995, Statistics for ornithologists. British Trust for Ornithology, Norwich.

HEIMERDINGER, M. A. \& LEBERMAN, R. C., 1966, Comparative efficiency of 30 and $36 \mathrm{~mm}$ mesh in mist nets. Bird-Banding, 37(4): 280.

JENNI, L., LEUENBERGER, M. \& RAMPAZZI, F., 1996, Capture efficiency of mist nets with comments on their role in the assessment of passerine habitat use. J. Field Ornithol., 67(2): 263-274.

KARR, J. R., 1980, Geographical variation in the avifauna of tropical forest undergrowth. Auk, 97: 283-298.

KARR, J. R., 1981, Surveying birds with mist nets. Studies in Avian Biology, 6: 62-67.

LOISELLE, B. A. \& BLAKE, J. G., 1994, Annual variation in birds and plants of a tropical second-growth woodland. Condor, 96: 368-380.
MacARTHUR, R. H. \& MacARTHUR, A. T., 1974, On the use of mist nets for populations studies of birds. Proc. Nat. Acad. Sci., 71(8): 3230-3233.

MARINI, M. A., MOTTA-JUNIOR, J. C., VASCONCELLOS, L. A. S. \& CAVALCANTI, R. B., 1997, Avian body masses from the cerrado region of central Brazil. Ornit. Neotrop., 8: 93-99.

ONIKI, Y. \& WILLIS, E. O., 1999, Body mass, cloacal temperature, morphometrics, breeding, and molt of birds of the Serra das Araras region, Mato Grosso, Brazil. Ararajuba, 7(1): 17-21.

PARDIECK, K. \& WAIDE, R. B., 1992, Mesh size as a factor in avian community studies using mist-nets. $J$. Field Ornithol., 63(3): 250-255.

PIRATELli, A. J., MELO, F. P. \& CALIRI, R. F., 2001, Dados morfométricos de aves de sub-bosque da região leste de Mato Grosso do Sul. Revta. Bras. Zool., 18(2): 305-317.

POUlin, B., LEFEBVRE, G. \& PILARD, P., 2000, Quantifying the breeding assemblage of reedbed passerines with mist-net and point-count surveys. J. Field Ornithol., 71(3): 443-454.

RAPPOLE, J. H., WINKER, K. \& POWELL, G. V. N., 1998, Migratory bird habitat use in southern Mexico: Mist nets versus point counts. J. Field Ornithol., 69(4): 635-643.

RALPH, C. J., GEUPEL, G. R., PYLE, P., MARTIN, T. E., \& DESANTE, D. F., 1993, Handbook of field methods for monitoring landbirds. Forest Service, U.S. Department of Agriculture, Albany, 41p.

REINERT, B. L., PINTO, J. C., BORNSCHEIN, M. R., PICHORIM, M. \& MARINI, M. A., 1996, Body masses and measurements of birds from southern Atlantic Forest, Brazil. Revta. Bras. Zool., 13(4): 815-820.

REMSEN Jr., J. V. \& GOOD, D. A., 1996, Misuse of data from mist-net captures to assess relative abundance in bird populations. Auk, 113: 381-398.

SILKEY, M., NUR, N. \& GEUPEL, G. R., 1999, The use of mist-net capture rates to monitor annual variation in abundance: a validation study. Condor, 101(2): 288-298.

STRATFORD, J. A. \& STOUFFER, P. C., 1999, Local extinctions of terrestrial insectivorous birds in a fragmented landscape near Manaus, Brazil. Conserv. Biol., 13(6): 1416-1423.

YOUNG, B. E., DEROSIER, D. \& POWELL, G. V. N., 1998, Diversity and conservation of understory birds in the Tilaran Mountains, Costa Rica. Auk, 115(4): 998-1016. 